\title{
민관협력사업과 시민사회(CSO)의 참여: 몽골 사례에서의 시사점
}

\author{
오 주 현 (KOICA 민관협력실 과장)
}

\section{목 차}

\author{
I. 들어가며 \\ II. 민관협력사업 이행성과 \\ III. 몽골의 민관협력사업 추진현황 및 시사점 \\ IV. 향후 시민사회(CSO)1)의 역할 및 방향 \\ V. 나가며
}

\section{I. 들어가며}

최근 개발협력의 담론이 ‘원조효과성’ 에서 ‘개발효과성’ 으로 이행되면서, 인권 · 여성 · 민주 주의 등 시민사회가 강조한 주제가 화두가 되고 있다. 이에 $\mathrm{KOICA}$ 의 민관협력사업도 기존의 전통적인 개발 $\mathrm{NGO}$ 중심의 지원에서 인권, 종교, 노동조합, 기업, 대학 등으로 참여대상이 확대 됨에 따라 변화된 국제환경 및 국제 원조규범과의 조화를 고려한 개발사업을 지원하는 형태로 변화하고 있다.

특히, '사업컨설팅+사업관리/모니터링+평가+역량개발' 이 종합적으로 연계된 지원방식에 대한 시민사회(CSO) 및 민간의 수요를 반영하여, 민관협력사업에 대한 프로그램을 브랜드화하고, 통합 브랜드 체계 하에 관련 사업수행 세부프로그램을 구성한 파트너십 구축을 위해 노력하고 있다.

1) 시민사회(CSO) : Civil Society Organization의 약자로, 개발NGO - 여성단체 - 의료보건단체 등 다양한 시민사회 해위자들이 국제개발협력에 참여. 이를 포괄하는 용어로 사용 중임. $\mathrm{CSO}$ 는 '08년 제 3차 원조효과성고위급회담 에서도 독립적인 주요원조행위자로 인정된 바 있음. 
더불어, $\mathrm{KOICA}$ 는 $\mathrm{OECD} / \mathrm{DAC}$ 국가들이 시행하고 있는 시민사회(CSO)협력프로그램 조사 · 분석 및 한국의 현황을 고려하여 시민사회(CSO)협력프로그램에 기여할 수 있는 사업들을 개발 하여 점진적인 도입을 준비하고 있으며, 민간부분과의 협력방안을 확대하기 위해 국내기업의 글로벌 사회공헌(CSR)과 $\mathrm{ODA}$ 를 연계하는 다각적인 방안을 검토하고 있다.

또한, 최근 $\mathrm{G} 20$, 부산세계개발원조총회(HLF-4) 등을 통해 개발효과성에 대한 중요성이 강 조되면서, 결과에 초점을 둔 개도국 중심의 맞춤형 개발 지원으로 패러다임이 전환되고 있다. 지난 부산총회 때에도 본회의 외에 다양한 포럼 및 부대행사2) 개최를 통해 개발협력의 새로운 이정표를 마련하였다. 그러므로 민관협력사업에서도 G20 개발의제 등 주요 개발협력 이니셔티 브와의 연계한 사업 추진 기반 구축이 필요한 시점이라고 할 수 있다.

물론, 금번 부산세계개발원조총회의 성과가 다소 제한적인 측면이 있지만 시민사회에서 주창 한 이스탄불 원칙, $\mathrm{RBA}^{3}$ )에 기반한 파트너십 및 민간부분의 역할 강화 등 향후 '부산 파트너 십’ 이행체제(Post-Busan mechanism) 구축에 기여하기 위한 시민사회(CSO) 및 민간부분의 역할은 확대될 전망이다. 무엇보다 오너십 · 리더십에 기반한 부산 파트너십의 성공적인 추진을 위해 협력기반을 마련하는 것이 중요하다고 할 수 있다. 이 과정에서 시민사회 및 민간부문의 의견 수렴 및 협력 강화가 필요하며, Post MDG와 연계하여 부산총회 합의사항 이행에 대한 기 반을 민관협력사업 차원에서도 마련해야 할 것이다.

더군다나, 2012년은 KOICA가 OECD DAC 개발협력정책 · 집행심사(Peer Review)를 받는 해이기도 하다. 2008년 DAC 특별검토결과 주요 권고사항 중, '대외원조 구조' 에 대한 조치사 항으로 '시민사회와의 협력 확대’ 가 언급된 바 있다. 상기 사유로, 본고에서는 그간 민관협력사 업 이행성과 고찰을 통해 체계적인 이행현황을 분석하고 및 몽골 지역에서 추진된 민관협력사 업의 실제 사례를 통해 시사점을 도출하고, 향후 개발원조에서 시민사회(CSO)의 역할 및 나아 가야 할 방향에 대해 모색해보고자 한다.

2) 주요포럼: 시민사회포럼( '11.11.26-28), 의회포럼(' 11.11.29), 청소년포럼( '11.11.29), 민간기업포럼(' 11.11.30) 부대행사: 50여개, OECD개발전략, G20개발의제 아웃리치 행사, 포용적 성장, 물과 개발, Making Reform Happen, 한국원조역사전시회 등

3) RBA : '인권에 기반한 접근', Rights-Based Approach의 약자로 최근 국제사회에서 인권과 개발의 양립을 위 해 논의되고 있으며, 국제인권규범에 근거하여 빈곤퇴치를 위한 개발사업을 실시한다는 의미 


\section{II. 민관협력사업 이행성과}

KOICA의 민관협력사업 예산규모는 1995년부터 현재까지 점진적으로 확대되어 왔으며, 특 히 지난 2010년 한국정부가 발표한 '국제개발협력선진화전략' 4)에 근거, 시민사회(CSO) 및 민 간부문에 대한 지원규모 확대 계획에 대한 결과가 가시적으로 도출되고 있다.

더불어, 그간 개별 $\mathrm{CSO}$ 의 사업수행 역량이 개선되어 단체별 사업수행 건수가 대폭 증가하였 으며, KOICA 사업에 참여하는 단체 및 지원국가 수가 확대되었다.

\section{〈KOICA의 민관협력사업 예산변화의 추이(1995 2012)〉}

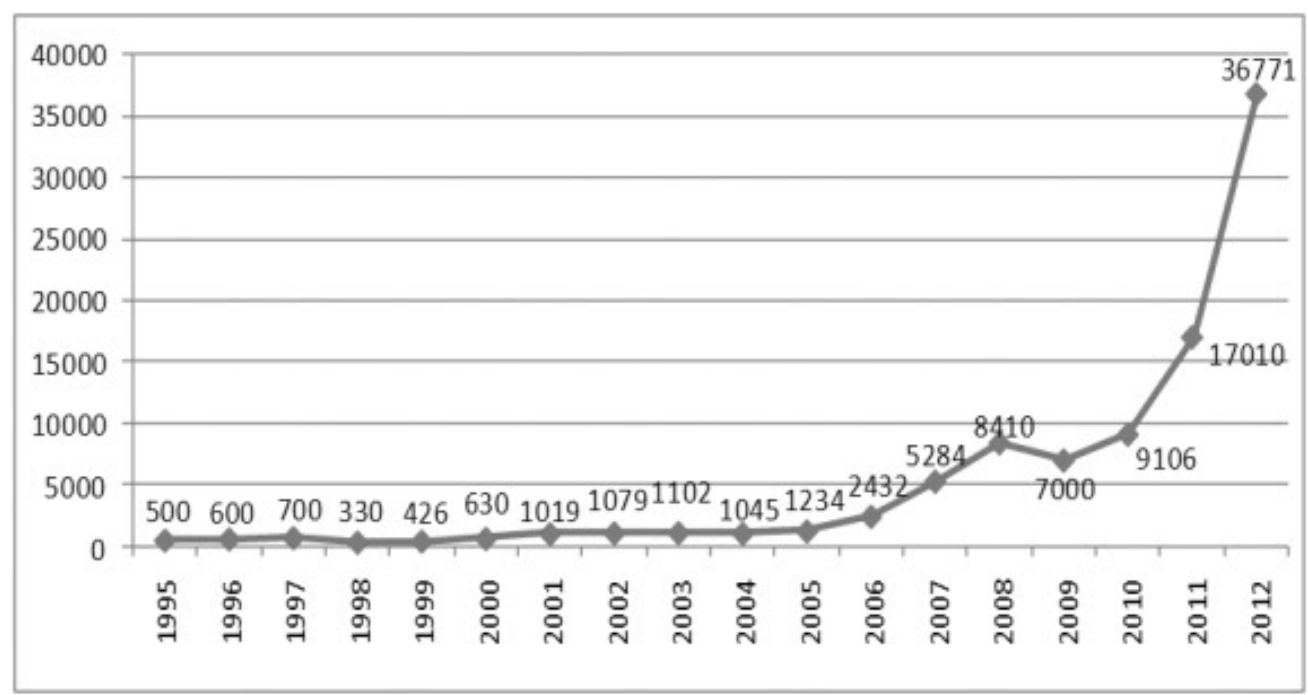

또한, $\mathrm{KOICA}$ 는 $\mathrm{CSO}$ 지원 사업에 2010년부터 다년도 사업을 도입하고 지원금에 대한 매칭규 모를 확대하여, 사업에 대한 예측성 및 안정적인 사업운영을 도모하고 있다. 또한, 국제개발협 력에 있어, 시민사회 참여 및 기여를 중요한 요소로 인정하고, 시민사회 기여를 최대화할 수 있 는 환경조성(Enabling Environment)에 협력하고 있다. 국제원조동향 준수를 통한 지원 프로 그램 강화 차원에서 시민사회 지원에 대한 매칭비율 확대 및 국내 $\mathrm{NGO}$ 의 취약한 인력 및 조직 운영 상황 등을 감안하여 간접비를 점진적으로 확대 지원할 예정이다.

4) '국제개발협력선진화전략' 


\section{〈KOICA NGO 지원금 매칭비율 현황 〉}

\begin{tabular}{c|c|c|c|c|c}
\hline 구분 & 2009년 & 2010년 & 2011년 & 2012년 & 2013년(잠정) \\
\hline 지원금지원비율 & $50 \%$ & $60 \%$ & $70 \%$ & $70 \%$ & $70 \sim 80 \%$ \\
\hline
\end{tabular}

\section{〈KOICA NGO 간접비 반영 현황 〉}

\begin{tabular}{c|c|c|c|c}
\hline 구분 & 2010년 & 2011년 & 2012년 & 2013년(잠정) \\
\hline 간접비 반영비율 & - & $5 \%$ & $6 \%$ & $7 \%$ \\
\hline
\end{tabular}

한편, 2008년까지 개발NGO대상 단일화된 사업프로그램 운영에서 개발협력이해증진 프로그 램(2009), 글로벌사회공헌(CSR)파트너십 프로그램(2010)을 신규 도입하여 실시함으로서, 민관 협력사업 참여의 폭이 확대되고 있다.

더불어, 사업에 대한 정보공유, 다양한 단체 및 기관 참여 확대를 위한 지원사업을 실시하고 있으며, 분야별 포럼 - 주제별 세미나 등 우량 사업발굴 기회를 확대하고 협력 네트워크 조성을 위한 공식 채널의 장을 마련하여 왔다. 국제개발협력 분야의 다양한 이슈를 선정하여, 해당분야 의 전문가 및 $\mathrm{CSO}$ 활동가들과 심도있는 토론의 장을 정기적으로 개최하고 있으며, $\mathrm{ODA}$ 사업 을 수행하는 단체들에게 필요한 정보와 네트워크를 제공하여 효과적인 사업을 수행하도록 지원 하고 있다.

한편, 향후 '국제개발협력선진화전략' 에 의거하여, 민관협력사업 규모가 2015년까지 약 900 억으로 확대될 예정임을 고려하여 체계적인 기반 마련 및 전략을 보완하기 위한 연구용역5)을 실시하기도 하였다.

$\mathrm{KOICA}$ 에서는 연구용역 결과를 참고하여 민관협력사업의 효과적인 추진을 위해 민관협력사 업 중기전략(2011-2015)을 수립하였고, DAC 가입이후 우리나라 민관협력사업의 발전방향을 모색하고 있다. 특히 중기전략에 근거하여, 기존 민간단체지원사업의 단일화된 사업추진체계에 서 다양한 사업추진방식을 도입할 예정이다.

5) 개발효과성 제고를 위한 정부-시민사회 협력방안 연구(2011.11)

효과적인 공공-민간파트너십 사업모델 연구(2011.8) 


\section{현지 CSO지원 사업을 실시}

전문성을 가진 파트너국 현지 $\mathrm{CSO}$ 를 지원하여 파트너 국가의 빈곤퇴치와 경제사회 발전에 기여

\section{현지사업장 Peer Review 실시}

시민사회의 사업수행 역량 강화를 위해 현지사업장을 서로 방문하여 상호학습, 개발사업 · 현지와 관련된 다양한 정보 공유, 사업평가

최근에는 사업선정-시행-평가 전반에 걸친 전략적이고 일관성 있는 사업추진을 도모하기 위 해 단위사업별 선택과 집중을 통한 프로그램 유형을 개선하였다. 즉, 연도별 각 사업추진 계획 을 수립하여, 사업별 모델 프로그램 개발계획 수립 하에 단계별로 실시하고, 프로그램 내용 · 실 시방법·모니터링 등에서 타 공여국의 선진사례들을 벤치마킹하되, 국제원조규범을 반영하고 사업수단간 연계성 제고 방안을 포함하는 프로그램을 개발하고 있으며, 프로그램별 특성을 고 려한 사업별 브랜드네임6)을 도입하였다. 기존에 ‘지원사업’ 이라는 사업명칭에서 더욱 폭넓고 다양한 주체의 참여(개발 NGO, 노조, 협동조합 등)를 통해 빈곤감소를 위한 사업을 수행할 수 있 는 개방적인 방향으로 사업을 운영하기 위해 '시민사회협력프로그램' 등의 명칭을 도입하였다.

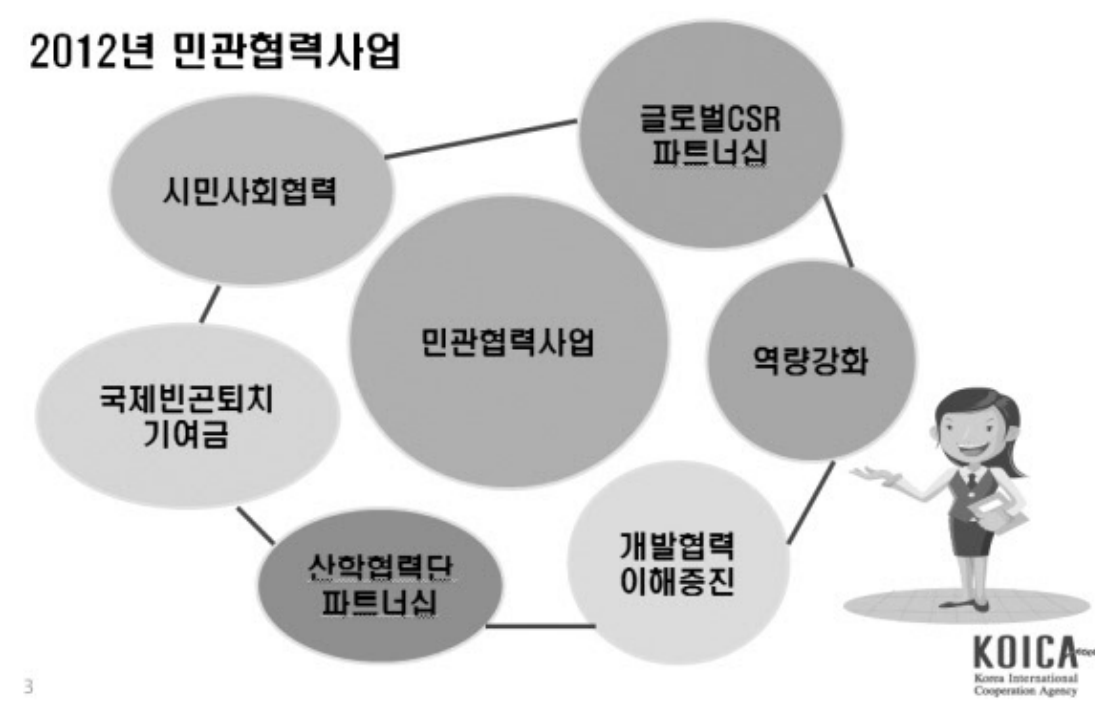

6) 그림 '2012년도 민관협력사업' 참조 
또한, 한국정부의 $\mathrm{ODA}$ 자금, $\mathrm{CSO}$ 지원규모 확대, 국제개발협력사업에 대한 사회적 관심 증가 등으로 $\mathrm{KOICA}$ 사업에 참여하고자 하는 단체 증가 추세를 고려하여 내실 있는 사업파트너기관 육성을 위해 2012년부터 사업발굴지원을 실시할 예정이다. 사업발굴지원은 사업발굴 및 기획 단계부터 단체에 대한 일련의 체계화된 컨설팅을 지원하는 사업으로 그간 시민사회의 지속적인 요청사항이 반영된 사업이라 할 수 있다.

\section{사업발굴지원}

$\mathrm{KOICA}$ 에서 제공하는 소정의 사업관리교육을 이수한 단체에 한하여, 사업공모 참여기회 부여 및 전문가 컨설팅을 통한 사업기획 및 관리 지원

$\mathrm{ex}$ )사업관리교육실시 $\rightarrow$ 사업공모(Concept Paper) $\rightarrow$ 전문가동반 사업컨설팅(현지조사포함) $\rightarrow$ 사업실행계획서 작성 $\rightarrow$ 사업약정체결

특히, 사업계획 당시 의도한 결과를 달성하고 다양한 사후관리 방안을 통한 사업의 지속가능 성을 확보하기 위해, 사업과정에 성과관리체계 및 도구(PDM 기법) 활용을 확대하여 성과 결과 중심의 평가체제로 전환하고 있다. 사업기획 단계부터 논리모형 및 지표활용을 통해 모니터링 및 평가계획을 수립하도록 하였으며, 평가결과에 대한 Feedback을 이행하도록 제도화한 것이 다. 이와 더불어, 사업계획서 개선 및 사업수행기관대상 성과관리 교육을 실시하고 있다.

더불어, $\mathrm{KOICA}$ 는 국내 시민사회(CSO)와 민간부문의 열악한 사업여건을 고려하여, 다양한 이해관계자들의 만족도를 제고할 수 있는 역량강화프로그램을 진행하고 있으며, 특히 전달방식 에 있어 다양화를 추진하고 있다. 대학산학협력단, 사회적 기업, 대학병원, $\mathrm{NGO}$ 등 다양한 참 여기관의 역할을 지원할 수 있는 사업지원 및 교육 프로그램을 운영하고 있다. 더불어, 개발 $\mathrm{NGO}$ 대표자들을 대상으로 한 연수프로그램 운영을 통해 효율적인 민관협력사업을 추진하기 위한 공감대를 형성하기 위해 그간 많은 노력을 기울여 왔다. 그 외에도 현지의 사업수행역량강 화를 위한 사업 및 현지직원교육 등을 추진하여 사업효과성 제고를 위한 많은 노력을 경주해 왔다.

한편, 급격한 대내외적 환경변화에 대한 한국 시민사회(CSO) 및 민간부문의 유연하고 적극적 인 대응책을 마련하고자 단체의 책무성 및 투명성증진을 위한 활동을 지원할 예정이다. 사업수 행 및 조직운영에서 책무성과 투명성 확보를 통해 개발원조 사업의 질을 제고할 수 있을 뿐만 아니라, 투명성과 책무성을 강조하는 국제사회 개발원조의 기준에 부합하는 개발원조사업을 수 행할 수 있어야 하기 때문이다. 
최근에는 선진공여국의 시민사회경험 및 민-관협력 경험을 공유하고 보다 효과적인 프로그램 운영을 위해 한국의 시민사회 조직 $(\mathrm{G}-\mathrm{CAP}, \mathrm{KoFid})^{7}$ 및 컨설팅 기관을 지원하여 국제 시민사 회와의 연계조직 강화를 지속적으로 지원하고 있다. 국제 시민사회가 주최하는 각종 세미나, 포 럼, 회의 등에 참여하여 지속적인 시민사회 네트워크 조성에 기여할 수 있도록 지원하고 있으 며, 국내 컨설팅 기관과 분야별 - 주제별 공동협력사업을 실시하여 민관협력사업의 다양한 이해 관계자들과 협력을 추진해 오고 있다.

\section{III . 몽골의 민관협력사업 추진현황 및 시사점}

본 장에서는 민관협력사업사업이 다수 추진되고 있는 동남아지역 중 몽골의 민관협력사업 추 진현황 및 시사점에 대해 살펴보기로 한다. 본 장에 기술되는 내용은 민관협력사업중 시민사회 협력프로그램, 즉 $\mathrm{NGO}$ 지원사업에 한정하여 기술하며, 2010년에 발간된 $\mathrm{NGO}$ 지원사업 종합평 가 보고서 및 사업별 중간 · 종료보고서 등에 근간을 두고 있음을 참고로 밝혀둔다.

\section{III-1. 몽골에 대한 개괄}

먼저, 몽골은 민간단체지원사업 부문에 있어 아시아에서 지원규모가 제법 큰 국가로 분류되고 있다. 몽골은 과거 오랜 기간 공산주의의 식민지화를 거치면서 보편적 초등교육의 이수율은 높 으나, 청소년들의 공동체성이 미비하고, 사회적 부적응, 주체의식 부족 등으로 청소년들이 각종 범죄에 노출되어 있고 전반적인 국민들의 사회적 책임 의식이 부족한 상태이다. ${ }^{8)}$ 몽골 정부 통 계청이 발표한 자료(2008년도)에 따르면 정규교육과정 1 11학년까지의 이수율은 $95 \%$ 이지만 청소년의 범죄율은 전체 범죄율 중 $55.1 \%$ 이라고 한다. ${ }^{9)}$

또한, 몽골은 총 인구 273만명(2009)으로 절대인구가 매우 적은 편이며, 문맹률 $2.7 \%$, 출생

7) G-CAP : Global Call to Action against Poverty, 지구촌빈곤퇴치를 비롯한 MDGs 달성을 위하여 활동하는 130여개국 NGO 국제연대체

KoFID : 국제개발협력시민사회포럼(Korea Civil Society Forum on International Development Cooperation) 은 한국의 시민사회단체가 국제개발협력의 효과성 증진을 위해 결성한 네트워크

8) 몽골의 전통과 민속보기, 박환영 저, 박이정 2008

9) Mongolia Statisticla year book 2008, p.393 National statistical office of Mongolia 
율 $21.5 \%$ 로 성장 가능선이 엿보임에도 불구하고, 유아 사망률이 $39.88 \%$ 에 달하며, 총 인구의 절반이 수도인 울란바타르에 집중되면서 도시 내 빈곤 계층의 수가 급증하고 있는 실정이다. 울 란바타르시에서 생활하는 사람들중에 $60.8 \%$ 가 시내 중심가에서 생활하고 있으며, 전체 인구 중 $80 \%$ 가 빈곤층에 속하고 있다. 특히 유아의 주된 사망원인은 경제적 빈곤으로 인한 각종 질 병이라 파악되고 있다.

몽골은 사회경제적 생활면에서 2 차 산업이 크게 발달하지 못한 단계로 생활에 필요한 대부분 의 것들을 수입에 의존하고 있으며, 경제적으로 세계 각국의 지원과 원조에 의존하고 있다. 2008년 몽골 통계에 따르면, 국민 1 인당 총수입(GDP)는 $\$ 1,920$ 이며, 세계은행 통계에 의한 국 민총생산량(GNP)은 $\$ 2,900$ 로 나타났다.

몽골은 전통적으로 국민들 대부분이 목축업에 의존하여 생활하고 있으나, 최근 목축업에 종사 하는 사람들이 경제생활의 어려움으로 인해 목축업을 포기하고 몽골의 수도인 울란바타르시로 이주하는 현상이 해마다 증가되고 있다. 도시민층으로 생활하는 사람들이 최근에 급속하게 증 가되면서 주거환경과 생활환경의 문제, 아동들의 양육과 교육 등 다양한 사회문제가 발생되고 있다. 특히 어려운 환경에 있는 몽골을 돕기 위해 활동하는 여러 국가의 INGO들을 볼 수 있다.

몽골의 교육환경은 대부분 공교육에 의지하고 있는 상태이며, 아직 사교육이나 정부차원에서 지원하는 방과 후 교육프로그램 등의 교육여건은 여러 면에서 열악한 상태이다. 하지만 빈부격 차에 따른 교육환경의 질은 많은 차이를 보이고 있다. 정부차원에서 방과후 교육 및 개인의 적 성개발과 증진을 위한 교육프로그램을 운영하는 장소가 있기는 하지만, 프로그램에 참여하기 위해 소요되는 비용은 $100 \%$ 이용자 부담으로 되어 있어, 이용자 대부분이 특정계층의 자녀들로 제한되는 경우가 많다. 물론, INGO나 종교단체에서 운영하는 방과후 교육프로그램이 있지만 재정적인 어려움과 인적자원의 부족으로 크게 활성화되지 못하고 있는 상태라고 할 수 있다.

또한, 몽골의 사막화, 황폐화의 심화로 인해 몽골 국민들의 삶의 질 저하 문제도 심각하다. 기 후변화로 인해 지난 60 년간 몽골의 연평균 기온은 $1.92^{\circ} \mathrm{C}$ 상승되었고, 강수량은 $2 \%$ 감소하였으 며 지난 50 년간 증발량은 $100 \mathrm{~mm}$ 증가한 것으로 보고되고 있다. 이로 인해 최근 10 여년간 많은 수의 우물, 샘, 호수 등이 고갈되고 있으며, 현재 국토의 $50 \%$ 가 사막화되었으며, $90.2 \%$ 가 사막 화 위기에 직면해 있다.(2009) 더불어, 무분별한 가축 방목으로 인하여 초원이 파괴되고 있으 며, 회복능력이 점차 상실되어 가고 있다. 이처럼 사막화로 인해 수도인 울란바타르시로 몰려드 는 환경난민이 급증하고 있는 실정이다. 
뿐만 아니라, 80년대 말까지 몽골 전체 경제의 $30 \%$ 이상을 차지하던 구소련의 지원이 소련 붕괴 이후 1990 년과 1991 년 사이 갑자기 중단되고 더불어 몽골의 정치적 혼란과 자연재난 등이 겹치면서 몽골 경제는 2002 년까지 장기 침체를 겪었으며, 그 결과 국제사회의 도움을 필요로 하는 빈곤국가에 머물고 있다.

이후 2000년 UN 회원국들이 빈곤문제 해결을 위해 MDGs 달성을 약속하면서 몽골도 외부 지원 및 몽골 정부의 노력 등을 통해 빈곤율이 감소하는 추세에 있다. 그러나 전체적인 빈곤율 은 감소한 반면, 도시외곽지역의 경우 오히려 빈곤율이 위에 언급한 여러 상황으로 인해 증가함 을 알 수 있다. 이는 도시 중심부보다 도시 외곽 및 농촌지역으로 갈수록 시장과의 거리, 기반시 설의 부족, 교육에 대한 제한된 기회, 부족한 정보 등에 기인한다고 볼 수 있다. 따라서, 몽골 환 경과 상황에 맞는 지역 중심의 개발 모델 지원을 통해 빈곤문제 해결이 필요하다. ${ }^{10)}$

\section{III-2. 몽골 민관협력사업 특징 및 시사점}

우선, 몽골에서 진행되고 있는 $\mathrm{NGO}$ 의 현황을 살펴보면 다음과 같은 특징을 살펴볼 수 있다. ${ }^{11}$

O 사업수행방식을 크게 국내 $\mathrm{NGO}$ 의 현지 지부가 직접 수행을 하는 경우와 몽골 현지 $\mathrm{NGO}$ 와 협력·위임하는 경우가 대부분임.

- 현지 $\mathrm{NGO}$ 와 협력·위임하는 경우는 국내NGO의 지원 및 사업협의, 원활한 의사소통에 기반한 사업수행, 단순한 예산지원 등의 협력이 이루어지기도 함.

O 사업지역은 대다수가 수도인 울란바타르 지역에 집중되는 경향이 있으며, 이러한 현상은 몽 골의 특징에 기인함.

- 울란바타르를 중심으로 도로, 통신 등 사회간접시설이 구축되고 있으며, 이로 인해 수도 로 유입되는 인구가 계속 증가 추세임.

- 특히, 수도 외곽에 주로 빈민층이 거주하는 게르촌이 확대됨에 따라 이들에 대한 사업수 요가 증가하고 있는 추세임.

10) 참고 : The Millenuim Develpment Goals Implementation 2nd National Report, Mongolia 2007 11) NGO지원사업 종합평가 보고서 p.151 몽골 현지평가 
O 사업책임자 형태는 단체의 본부에서 파견한 형태와 현지협력기관에 위임한 형태로 크게 구분됨.

O 사업내용은 주로 지역개발과 특정 단일분야 지원사업의 형태로 구분됨.

- 지역개발은 도시 지역에서 2 개 이상의 분야 및 Target group을 대상으로 하여 진행되는 도시지역개발사업(Urban Development)과 지방에서 2개 이상의 분야 및 Target group을 대상으로 하여 수행되는 지방지역개발사업(Rural Development)

- 특정 단일분야 지원사업은 주로 의료, 교육, 주거의 형태로 나타나며, 지속적으로 사업이 이루어지는 교육의 경우 효과적인으로 보임.

참고로, 최근 3 년간 몽골에서 진행된 민간단체지원사업 목록이다.

\begin{tabular}{|c|c|c|c|}
\hline 연도 & 국가 & 단체명 & 사업명 (사업내용) \\
\hline \multirow[t]{7}{*}{2009} & \multirow[t]{7}{*}{ 몽골 } & $\begin{array}{l}\text { 시민정보 } \\
\text { 미디어센터 }\end{array}$ & 몽골 바양노르군(郡) 사막화방지를 위한 조림사업 \\
\hline & & 인구보건복지협회 & 몽골 청소년 성생식보건 사업 \\
\hline & & 지구촌공생회 & $\begin{array}{l}\text { 몽골 게르촌 도시빈민을 위한 청소년 문화센터 } \\
\text { 및 식수지원 사업 }\end{array}$ \\
\hline & & 지구촌나눔운동 & $\begin{array}{l}\text { 몽골 유목민 정착을 위한 축산시범마을 } \\
\text { 보급사업 }\end{array}$ \\
\hline & & 하트하트재단 & $\begin{array}{l}\text { 몽골 울란바타르 칭글테 결식아동 } \\
\text { 건강증진 사업 }\end{array}$ \\
\hline & & $\begin{array}{l}\text { 한마음한몸 } \\
\text { 운동본부 }\end{array}$ & $\begin{array}{l}\text { 몽골 울란바타르 지역 청소년을 위한 } \\
\text { 교육지원사업 }\end{array}$ \\
\hline & & 한몽교류진흥협회 & 몽골 울란바타르시 종묘지원사업 \\
\hline
\end{tabular}




\begin{tabular}{|c|c|c|c|}
\hline 연도 & 국가 & 단 명 & 사 업 명 (사업내용) \\
\hline \multirow{7}{*}{2010} & \multirow{7}{*}{ 몽골 } & 위드 & 몽골 학교급식 시범학교 운영사업 \\
\hline & & 하트하트재단 & $\begin{array}{l}\text { 울란바타르 칭글테, 수흐바타르 구 결식아동 } \\
\text { 건강증진사업 }\end{array}$ \\
\hline & & 지구촌공생회 & 몽골 게르촌 농업교육사업 \\
\hline & & 지구촌나눔운동 & $\begin{array}{l}\text { 몽골유목민 정착을 위한 축산시범마을 } \\
\text { 보급사업 }\end{array}$ \\
\hline & & 푸른아시아 & $\begin{array}{l}\text { 몽골 바양노르솜 사막화.황사방지 성공 } \\
\text { 모델 구축을 위한 조림사업 }\end{array}$ \\
\hline & & 한국가톨릭의료협회 & 몽골 다르항 제1병원 안과 지원사업 \\
\hline & & 한마음한몸운동본부 & $\begin{array}{l}\text { 몽골 울란바타르 지역 청소년을 위한 교육지원 } \\
\text { 사업 }\end{array}$ \\
\hline
\end{tabular}

\begin{tabular}{|c|c|c|c|}
\hline 연도 & 국가 & 단 명 & 사 업 명 (사업내용) \\
\hline \multirow{8}{*}{2010} & \multirow{8}{*}{ 몽골 } & 한국가톨릭의료협회 & $\begin{array}{l}\text { 몽골 다르항시 아동, 청소년을 위한 학교보건 } \\
\text { 시스템 구축 }\end{array}$ \\
\hline & & 지구촌나눔운동 & $\begin{array}{l}\text { 몽골 사료은행 정착 및 지속가능한 축산시범마 } \\
\text { 을 모델 보급사업 }\end{array}$ \\
\hline & & $\begin{array}{l}\text { 한마음한몸 } \\
\text { 운동본부 }\end{array}$ & $\begin{array}{l}\text { 몽골 울란바타르 지역 청소년을 위한 교육지원 } \\
\text { 사업 }\end{array}$ \\
\hline & & 푸른아시아 & $\begin{array}{l}\text { 몽골국 초등학생 학교 수업 전과 방과 후 학습 } \\
\text { 지도 및 적성개발 증진 }\end{array}$ \\
\hline & & 위드 & 몽골 만성질환 예방 및 보건영양교육 시범사업 \\
\hline & & 코피온 & $\begin{array}{l}\text { 몽골 체쯔 지역 직업훈련 및 일자리 창출 사업 } \\
\text { 및 아동가족 지원사업 }\end{array}$ \\
\hline & & $\begin{array}{l}\text { 라파엘 클리닉 } \\
\text { 인터내셔널 }\end{array}$ & $\begin{array}{l}\text { 몽골 울란바타르 항올구 학생구강보건과 만성 } \\
\text { 질환 관리 개선사업 }\end{array}$ \\
\hline & & 위드 & $\begin{array}{l}\text { 몽골 바양노르솜 사막화.황사방지 성공모델 } \\
\text { 구축을 위한 조림사업 }\end{array}$ \\
\hline
\end{tabular}


상기 몽골에서 진행된 $\mathrm{NGO}$ 지원 사업외에도 그간 몽골에서 진행된 사업들에 대해 적절성, 효 율성, 효과성, 영향력, 지속가능성 측면에서 분석해 보면, 그 결과는 아래와 같다. ${ }^{12)}$

O (적절성) 사업발굴시 몽골의 국가발전계획이나, 사업지역 정부의 발전계획 고려, 사업목적 에 맞는 사업지역의 선정 등 대체적으로 필요성에는 공감을 하고 있으나, 실제 사업계획서 작성 시 정확하게 반영하고 있지는 못한 한계점이 들어남. 단, 해당 사업지역의 지방정부와 는 상대적으로 활발한 교류가 이루어지고 있는 바, 향후 협의 과정에서 발전전략에 대한 고 려가 가능할 수 있을 것으로 보임.

희망적인 요소는 몽골 내 한국 $\mathrm{NGO들에} \mathrm{대한} \mathrm{평가는} \mathrm{매우} \mathrm{긍정적이며} \mathrm{특히} \mathrm{'주민밀착형'}$ 사업 수행에 대한 만족도가 높은 편임. ${ }^{13)}$

$\mathrm{O}$ (효율성) 사업수행기관들은 한국의 단체 본부와 사업관련 의사소통을 정기적으로 진행하고 있으며, 대체로 주간단위, 월간단위의 보고 및 협의를 진행하고 있고, 사안 발생 시마다 활 발히 의사소통을 하고 있음.

또한, 대체적으로 현지 지역사회와의 공식적이고 정기적인 의사소통을 하고 있으며, 단순한 사업별 설명회부터 사업의 지속가능성을 염두에 두고 협의가 진행되는 등 각 단체들의 역량에 따라 편차는 다양한 것으로 나타남. 사업지역의 해당 지방정부는 지원사업에 대해 잘 인지하고 있는 편이나 구체적인 지원, 협의, 평가에의 참여도는 각 지방정부의 상황에 따라 다르게 나타남.

$\mathrm{O}$ (효과성) 사업의 효과적인 수행을 위해 전임 형태의 현지 사업 책임자를 두고 있으며, 한국 본부에서 파견되어 장기간 지속성을 두고 사업을 추진하는 경우와 단기간(1 2년)으로 고 용·파견되는 계약직 형태로 사업을 수행하는 경우, 사업운영의 전문성, 안정성 및 장기적 지속가능성에 차이가 존재함.

O (영향력) 대체적으로 사업 지역내 여성들의 역량강화에 있어서는 비교적 많은 영향을 주고

12) NGO지원사업 종합평가 보고서 p.153 157 참고

13) 사업수혜지역의 힌지 지역정부 관계자들, 주민평가, 외국인관리청 관계자의 평가에서 드러남. 
있으나, 사업발굴부터 수행에 이르는 과정에 적극적으로 고려되거나 반영되기 보다는 사업 분야가 여성과 관련이 큰 아동을 대상으로 하거나 교육, 보건 등 여성과 밀접한 사업 내용에 의해 간접적으로 영향을 미치고 있는 것으로 보임.

환경 분야의 경우 개발도상국이라는 몽골의 특징상 적극적인 고려와 인식이 많이 부족한 편이 긴 하나, 농업이나 조림 등을 기반으로 한 지역개발사업에서는 환경오염을 고려한 사업수행이 활발히 이루어지고 있음.

O (지속가능성) 현지에서 수행되고 있는 사업의 대부분이 KOICA의 지원이 사업의 초기단계 부터 전반적으로 절대적인 영향을 미치고 있음. $\mathrm{KOICA}$ 의 지원이 없을 경우를 대비하여 타 기 관으로부터 지원을 고려하는 단체도 있지만, 실질적인 실행에 있어서는 어려움을 겪고 있는 상 황임.

대다수의 사업수행기관이 사업 종료 후 지역사회로 사업을 이양해야 한다는 점에 대해 명확히 인식하고 있으나 실제로 구체적인 실행계획을 마련하지는 못하고 있는 실정임. 다만, 사업 진행 과정에서 일부 사업을 현지 지역사회에 이양하기 위한 협의를 진행하고 있는 경우도 있음.

상기 언급된 사항을 살펴보면, 사업수행기관의 현황 및 특성에 있어 사업수행방식과 사업 책 임자 형태는 사업의 지속성 및 안정적 운영에 큰 영향을 미치는 것으로 나타난다. 그리고 사업 발굴시 현지 국가의 발전계획이나 사업지역 정부의 발전계획 반영 여부가 보다 체계적인 사업 수행을 위해서는 고려되어야 함을 알 수 있다. 또한, 현지 지역사회와의 의사소통이 사업의 원 활한 수행을 위해 중요하며, 사업에 대한 지속적인 설명과 더불어 현지화하기 위한 준비도 사업 설계 단계부터 고려되어야 됨을 알 수 있다.

\section{IV. 향후 시민사회의 역할 및 방향}

$\mathrm{OECD} \mathrm{DAC} \mathrm{가입} \mathrm{및} \mathrm{ODA}$ 규모확대에 따라 민관협력사업 규모도 확대될 예정이다. $\mathrm{KOICA}$ 민관협력사업에서도 사업의 중심축을 현장으로 이동하여 현장중심으로 사업체계를 개편하여 효과적인 민관협력사업 관리 및 운영을 할 예정이다. 프로그램별 맞춤형 기획과 현지수요에 대 한 신속하고 유연한 대처를 위해 '프로그램의 현장화' 는 필수적이다. 우선, 민관협력사업 규모 
가 큰 국가들을 대상으로 민관협력사업 전문Desk를 설치하여 현지전문가· NGO - 기업 등을 활용한 사업발굴, 형성, 기획, 집행 및 모니터링 등 현지수행업무가 확대될 전망이다. 시민사회 (CSO)에서도 현지와 밀착된 사업을 효과적으로 추진하기 위해서는 지금보다 더 현지수요를 반 영한 사업을 발굴하는 것이 필요하다.

또한, 시민사회(CSO) 및 기업 등 민간부분에서 제안한 사업에 대한 평가를 통해 성과가 우수 한 모범사례(Best Practice)를 선정하여 향후 전략 사업 모델로 집중 지원하고자 한다. 그러나, 모범사례 발굴에 있어 일시적인 가시성 효과에 근간을 두는 사업보다, 사업이 실시된 이후 수혜 지역 및 지역주민들의 삶의 개선 등 사업의 지속성(Sustainability) 및 적절한 출구전략(Exit Plan)을 통해 사업이 현지 주민들에게 이양되어 자립적인 운영이 가능한 상태 등 종합적인 검 토를 통해 모범사례를 발굴하고자 한다.

더불어, $\mathrm{OECD} / \mathrm{DAC}$ 국가들이 시행하고 있는 $\mathrm{CSO}$ 협력프로그램에 대한 조사· 분석 및 한국 의 현황을 고려하여 $\mathrm{CSO}$ 협력프로그램 발전에 기여할 수 있는 프로그램을 개발14)하여 점진적 으로 도입할 예정이다.

\section{특정지역 및 분야지원사업}

정부의 원조정책과 긴밀한 연계를 통해 특정한 지역이나 분야에서 활동하는 $\mathrm{CSO}$ 를 지원

\section{혁신적개발지원사업}

전통적인 개발사업수행의 형식과 콘텐츠가 아닌 방식으로 진행되는 사업으로 개발NGO외 에도 다양한 시민사회의 구성원들이 참여할 수 있도록 유도

\section{전략적파트너지원사업}

다년지원, 대규모자금, 자금집행의 자율성 등을 특징으로 하여 전략적 파트너와 포괄협약 (Framework Agreement)을 맺어 지원

14) 표 참조 
그러나, 상기 표에 명시된 사업들이 KOICA 민관협력사업의 시민사회협력프로그램 속에서 실시되기 전에 선행되어야만 하는 전제조건들이 있다. 그중 하나가 바로 전략적파트너지원사업 을 실시하기 전에 도입되어야 하는 인증제도(Accreditation)이다. 좀 더 구체적으로 살펴보면, 전략적파트너지원사업은 $\mathrm{KOICA}$ 로부터 지원받은 재정의 사용에 대한 자율성을 갖는 다는 특징 이 있다. 물론 사업실행 전 $\mathrm{KOICA}$ 와 포괄적 협약을 체결하는 과정에 있어 충분한 협의과정을 거치지만, 전략적파트너지원사업에 참가하는 단체는 세부사업을 구성함에 있어 단체의 우선순 위에 의한 목표설정과 전략에 따라 재정배분을 자율적으로 구성할 수 있다. 다시 말해, 사업의 수, 지역, 분야에 있어 단체가 주도적인 결정권을 갖게 된다. 상기 사유로, 전략적파트너지원사 업은 다른 사업들과는 달리 장기간 큰 규모의 자금이 개별 단체에 지원되므로 대상단체 선정에 있어 면밀한 심사가 필요하다.

그러므로, 전략적파트너지원사업은 기본적으로 '인증제도'를 기반으로 실시할 수 있다. 즉, 동 사업에 지원하는 $\mathrm{CSO}$ 들이 '인증제도'를 통해 인증을 받고 지원자격을 갖춘 후, '심사위원 회’ 를 통해 최종 지원여부를 결정하는 것이다. 물론 인증제도가 기본적으로 $\mathrm{CSO}$ 를 등급화한다 거나 분류하기 위한 수단은 아니다. 인증제는 일정 수준 이상의 조직적, 인적, 재정적 역량을 갖 춘 단체임을 공식적으로 인증하는 제도로 인증과정에 참여한 $\mathrm{CSO}$ 가 단체의 다양한 역량에 대 해 객관적으로 평가받을 기회를 갖을 수 있는 일종의 컨설팅적 성격이 있으며, 이 과정에서 $\mathrm{CSO}$ 의 역량이 강화되는 계기가 될 수 있다.

\section{인증제도의 기대효과 ${ }^{15)}$}

$\sqrt{ }$ 전략적파트너지원사업에 참여자격 부여

$\checkmark$ 정부, 기업, 국제기구, 재단 등 외부 공여자들에게 신뢰제고

$\sqrt{ }$ 회원, 임직원 등 내부 관계자들의 자긍심 고양

$\checkmark$ 단체의 조직적, 인적, 재정적, 사업적 분야에 대해 수행되는

역량평가를 통한 조직진단, 단체 성장에 기여

$\sqrt{ }$ 대외적인 인지제고 및 홍보활동에 기여

15) 개발효과성 제고를 위한 정부-시민사회 협력 방안 연구 pp.118 
인증제도는 한국사회에서 아직 도입되지 않은 제도로 파급효과가 적지 않을 것으로 예상된다. 그러므로, 시행전에 시민사회(CSO)와의 충분한 의견수렴 과정이 필수적이며, 인증제도의 핵심 인 '인증집행기관' 선정도 철저한 준비가 필요하다. 인증집행기관은 외부 전문기관으로 하되, 인증절차에 필요한 인증위원회는 $\mathrm{KOICA}$ 관계자, 시민사회 전문가, 개발협력 전문가, 법률, 회 계전문가 및 분야별 - 지역별 전문가 등으로 구성될 수 있을 것이다. 인증에 대한 유효기간을 설 정하고, 인증을 받지 못한 단체는 재신청할 수 있는 절차 등이 마련되어야 한다.

인증제도 진행절차 ${ }^{16)}$

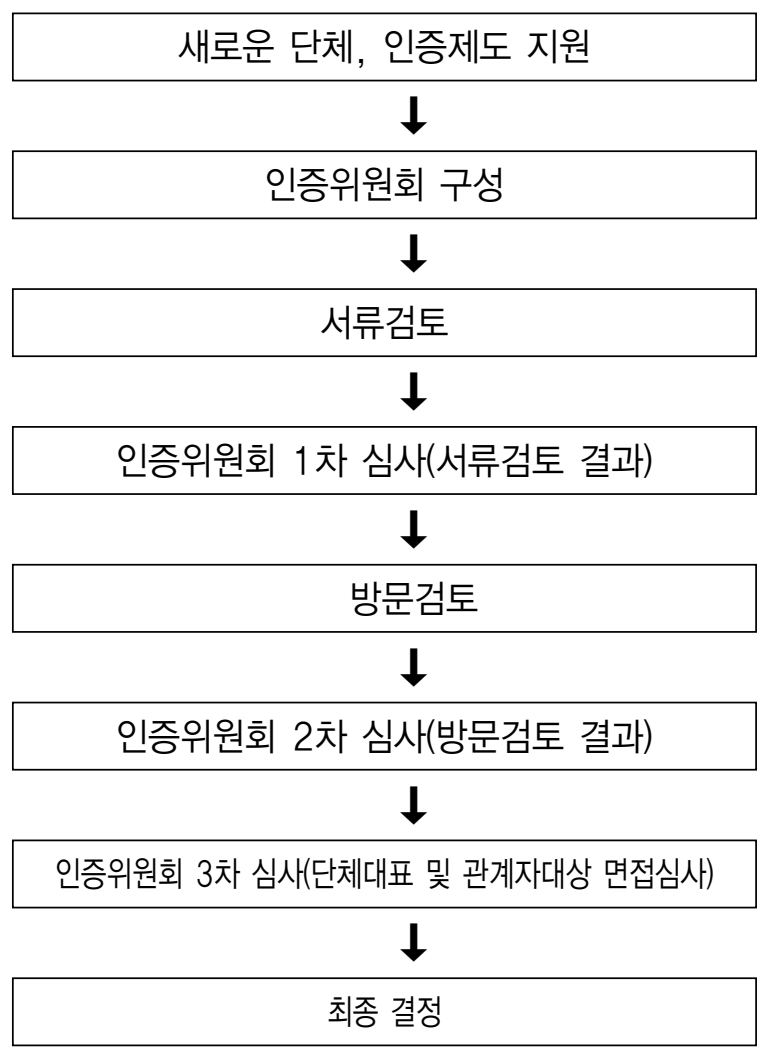

16) 개발효과성 제고를 위한 정부-시민사회 협력 방안 연구 pp.121 그림 6-4 요약으로 확정된 프로세스는 아님을 밝혀둔다.

17) CCC : Cooperation Committee for Cambodia 
인증제도를 실시한 오랜 경험을 보유한 호주의 AusAID나 개발도상국 $\mathrm{CSO}$ 로서는 성공적인 자체 인증관련 프로그램을 보유하고 있는 캄보디아 $\mathrm{CCC}^{17}$ )의 Voluntary NGO Certification System은 전략적파트너지원사업을 위한 인증제도에 많은 시사점을 주고 있다. 향후 우리나라 시민사회(CSO)의 역할이 증대될 것이며, 이에 따른 시민사회의 책무성 및 투명성도 동시에 강 화될 것이다. 이런 관점에서 시민사회도 단체의 역량을 키우고 전문적인 $\mathrm{CSO}$ 로 거듭날 수 있도 록 사전에 준비를 해야 할 것이다.

\section{V. 나가며}

최근 들어, 민관협력사업에 대한 관심 및 예산이 증대하면서 우후죽순으로 여러 $\mathrm{NGO}$ 들이 생 겨나고 있다. 이들 중 일부 단체의 경우 사업 내 단기 봉사단 혹은 의료단 파견 등의 사업이 구 성되어 있는데, 이러한 활동의 경우 사업에 대한 홍보 효과는 높을지 모르나, 제한된 예산 범위 내에서 자원을 효율적으로 사용해야 한다는 관점에서 본다면 투입비용에 비해 실질적인 개발효 과가 저하되는 경향이 있는 것이 사실이다. 단기적이거나 일회성의 의료봉사활동이나 소모품 등과 같은 물자지원 위주의 사업보다는 장기적이고 현지에 기술을 이전할 수 있어 현지 주민들 의 자립역량이 키워질 수 있는 사업들이 성공적이며 안정적으로 진행될 수 있다.

또한, 민관협력사업은 다양한 이해관계자(Stakeholders)가 수행하는 사업으로, 사업수행 국 가에 대한 깊은 이해와 현지 지역주민의 협조가 필수적이다. 이런 이유로, 현지 NGO단체 및 정 부기관, 주민의 의견을 도출하여 이를 바탕으로 사업을 추진하는 형태가 대부분이다. 무엇보다 적절한 사업대상지를 선정하고 지역특성에 맞는 사업 분야를 선정하여 지역주민들의 적극적인 참여를 유도하는 것이 중요하다. 특히, 지역 주민들의 참여도는 사업의 효과성을 제고시키는 데 중요한 역할을 하므로 사업 시행 전 반드시 고려해야 할 요소이다.

더불어, 개발 $\mathrm{NGO}$ 를 비롯한 다양한 사업수행기관의 실질적인 지원에도 불구하고 사업종료 후 시설물 방치 및 미활용 등 사후관리에 대한 고려도 사전에 이루어져야 한다. 지금까지 민관 협력사업을 추진하는 과정에서 얻는 시사점은 사업을 수행하는 기관들이 주민들의 의식개선을 통해 자발적인 운영관리를 도모하기 위한 사업관리자의 상주 여부가 성공에 있어 중요한 요인 으로 보인다. 
대부분의 사업수행에 있어 사업관리는 현지인에 의존하고 있고 한국인 관리자는 연간 $2 \sim 4$ 회 정도 방문하여 현장을 점검하는 정도로 진행되는 경우가 많았다. 그러다 보니, 사업에 대한 모 니터링 및 관리의 효율성에 의문을 제기하지 않을 수 없다. 물론, 현지인을 통한 사업관리가 체 계적으로 이루어져 안정적으로 사업관리가 진행된다면 좋겠지만, 현재까지 사업수행체계로 보건 데, 사업의 효율적인 운영측면에서는 한국인 관리자 파견이 사업의 성패에 큰 역할을 하고 있다.

물론 일부 단체에서는 안정적으로 사업관리자를 파견하기 위한 비용부담, 인력수급, 열악한 근무환경 등의 어려운 측면을 제기하기도 할 것이다. 이러한 관점에서 $\mathrm{KOICA}$ 에서는 지원금내 일정부분을 관련 행정비용으로 집행할 수 있도록 지원하고 있으며, 동 지원 규모를 점진적으로 확대해 나갈 예정이다. 이처럼 민관협력사업을 추진함에 있어 내실 있는 사업관리를 위해서는 $\mathrm{KOICA}$ 의 재정적인 지원뿐만 아니라, 단체들이 직접 일정기간동안 사업관리자를 파견(3개월 이상)하여 사업이 나아갈 방향을 제대로 잡아 주는 노력이 병행되어야 할 것이다.

지금까지 $\mathrm{KOICA}$ 민간단체지원사업에 지원하는 대다수의 개발 $\mathrm{NGO}$ 들은 사업의 발굴을 위해 현지 자체 사무소를 통한 방식을 가장 많이 활용하고 있는 것으로 나타났다. 그러나 이 과정에 서 $\mathrm{NGO}$ 의 본부 및 현지 관계자들은 대체적으로 사업발굴과정에서 파트너국의 중앙정부나 지 방정부의 발전계획을 고려치 않고 사업을 발굴하는 경향이 있어 왔다. ${ }^{18)} \mathrm{KOICA}$ 에서는 이러한 점을 고려하여, 2012년부터는 사업계획서 양식을 변경하였고, 충실한 Baseline survey 및 사 전조사 여부가 중요한 요소가 되고 있다. 일부 단체의 경우, 사업발굴 시 현지수요보다는 단체 의 상황으로 사업을 발굴한 경우도 있는 바, ${ }^{19)}$ 사업의 효과성 및 체계적인 관리운영을 위해서 사업의 투입요소도 중요하지만 향후 다양한 사업활동(Activities)들을 통해 직접적인 산출물 (Outputs), 나아가 지역발전에 기여하는 중장기 목적(Outcomes)과 파급효과(Impact)을 고려 하는 사업 추진이 중요할 것이다.

앞으로 민관협력사업의 특수성을 고려해 민관협력사업에 맞는 평가기법을 개발하여 사업이 실제 개발에 어떻게 영향을 주었는지에 대해 좀 더 종합적이고 체계적인 평가시스템을 구축할 예정이다. 이와 더불어, 독립적인 외부평가단의 참여 및 $\mathrm{NGO}, \mathrm{KOICA}$, 현지정부 및 지역사회 가 참여하는 평가결과 워크솝을 개최하여 사업에 대한 책임성을 제고하고 정기적으로 민관협력

18) NGO지원사업 종합평가 보고서(2010.12) p.15

19) NGO지원사업 종합평가 보고서 p.121 
사업 전반에 대한 평가보고서 발간을 통해 사업수행기관들의 성공적인 사업추진에 대한 이해도 를 제고하고자 한다.

결론적으로 민관협력사업은 $\mathrm{KOICA}$ 의 정부간 사업보다 사업수행방식과 사업책임자 형태에 따라 사업의 지속성 및 안정적인 운영에 영향을 더 받는 경향이 있으며, 해당 사업을 수행하는 기관들의 전문역량 강화에도 밀접한 연관성이 있다. 또한, 현지사업수행 기관과 사업수행기관 의 본부간 정기적 의사소통은 사업의 성공적인 추진에 있어 중요하다. 더불어, 단체가 자체적으 로 사업에 대한 내 외부평가 시스템을 갖추고 있는 경우 사업의 효과가 높은 것으로 나타나고 있다.

그러나 무엇보다 핵심적인 사항은 사업의 사후관리 및 지속가능성을 고려한 사업을 추진해야 하고, 이는 사업계획시부터 체계적으로 출구전략을 마련해야만 한다. 즉, 현지 사업의 효과성은 사업의 지속가능성과 밀접한 연관성이 있으므로, 사업설계시부터 출구전략(Exit Plan)을 수립 하고 구체적으로 사업내용을 기획하되, 현지 지역사회와의 협의를 통한 지속적인 보완이 중요 하다. 특히, 지역개발사업의 경우 소득증대, 고용창출, 환경개선 등 복합적인 효과성을 단기간 에 판단하기에는 어려운 점이 있으므로, 앞으로 다년도 사업으로 지원되는 사업들의 경우 일정 사업기간 이후 지속가능성 및 출구전략에 대한 평가를 실시하여 사업에 대한 효과성을 지속적 으로 증진시켜 나갈 예정이다. 